\title{
IMPLEMENTASI SERVQUAL DALAM MENINGKATKAN MUTU LAYANAN PADA MANAJEMEN PEMASARAN PENDIDIKAN
}

\author{
Rofiq Hidayat \\ IAIN Jember \\ elishaqy@yahoo.com \\ DOI: https://doi.org/10.35719/jieman.v2i1.17
}

\begin{abstract}
Abstrak
Banyaknya lembaga pendidikan yang tidak memberikan pelayanan dengan baik mempengaruhi dalam kepuasan pelanggan pendidikan. akibatnya penerimaan peserta didik baru semakin menurun hingga berujung pada sekolah yang digabung atau ditutup karena jumlah peserta didik tidak sesuai pagu. Untuk itulah perlu adanya peningkatan mutu layanan dalam sebuah manajemen pemasaan pendidikan di lembaga pendidikan dalam rangka menyongsong revolusi industri 4.o. Fokus kajian kali ini adalah bagaimana standar pelayanan pada manajemen mutu terpadu, bagaimana kesenjanganan antara produsen dan pelanggan pendidikan bisa terjadi, dan bagaimana Servqual RATER (Reliability, Assurance, Tangible, Empathy, dan Responsiveness) bisa menjadi solusi sekaligus imlplementasinya di era revolusi industri 4.o. Melalui metode analisis deskriptif, hasil implementasi Servqual tersebut ada pada bagaimana mengimplementasikan RATER dengan konsep manajemen pemasaran era revolusi industri 4.0 yang memiliki tiga ciri, yaitu dari eksklusif ke inklusif, dari vertikal ke horisontal, dan dari individual ke sosial.
\end{abstract}

Kata Kunci: manajemen pemasaran pendidikan, mutu layanan, Servqual 


\begin{abstract}
Many educational institutions do not provide services well for the satisfaction of education customers. As a result, accepting new students decreases to the point where schools are demerged or closed because the number of students does not meet the requirements. To help, it is necessary to improve the quality of services in the management of education at the Educational Institutions in the context of welcoming the industrial revolution 4.0 era. The focus of this study is how the service standards in integrated management, how to manage the handling between suppliers and customers Education can occur, and how Servqual RATER (Reliability, Assurance, Tangible, Empathy, and Responsiveness) can be a solution as well as its implementation in the Industrial Revolution 4.0 era. Through the descriptive analysis method, the results of this Servqual implementation exist when implementing RATER with the Marketing Management concept of the Industrial Revolution era 4.0 which has three features; from exclusive to inclusive, from vertical to horizontal, and from individual to social.
\end{abstract}

Keywords: marketing management services, quality of education, servqual

\title{
Pendahuluan
}

Setiap lembaga pendidikan memiliki tujuan untuk melaksanakan tujuan pendidikan nasional sebaik-baiknya. Sebagaimana amanat dalam Undang-Undang Nomor 20 tahun 2003 tentang Sistem Pendidikan Nasional, Pasal 3, lembaga pendidikan dituntut untuk bisa mengembangkan potensi peserta didik agar menjadi manusia yang beriman dan bertakwa kepada Tuhan Yang Maha Esa, berakhlak mulia, sehat, berilmu, cakap, kreatif, mandiri, dan menjadi warga negara yang demokratis serta bertanggung jawab. Untuk mencapai tujuan itu lembaga pendidikan haruslah memberi kualitas pelayanan yang sebaik-baiknya. Sebagaimana firman Allah dalam surat ali Imran: 110 dan surat Al Isra: 7 bahwa kita harus menjadi sebaik-baiknya manusia. Bahkan Nabi SAW menambahkan dalam musnad Ahmad:

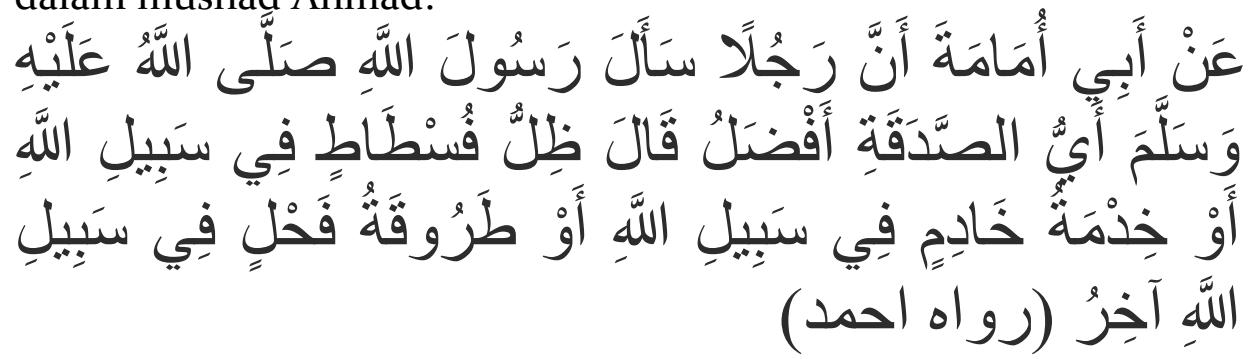


Artinya: Dari Abu Umamah bahwa seseorang bertanya kepada Rasulullah SAW: Sedekah apa yang paling utama? Rasulullah shallallahu 'alaihi wa sallam bersabda: "Naungan tenda di jalan Allah, memberi pelayanan di jalan Allah, dan menambatkan hewan di jalan Allah." HR Ahmad No. 21287.

Berdasarkan hadits tersebut, jelas bahwa pendidikan merupakan salah satu bentuk pelayanan di jalan Allah. Karena menuntut ilmu hakekatnya adalah wajib dan diangkat derajatnya oleh Allah (QS. Al-Mujadalah: 11). Lembaga pendidikan pada dasarnya ada untuk memberikan pelayanan kepada masyarakat yang menggunakan jasanya, yaitu pelanggan pendidikan. Dalam menjalankan fungsinya, lembaga pendidikan memiliki ciri-ciri yang berbeda dengan perusahaan berbasis bisnis, tetapi dalam menjalankan misi, tujuan dan programnya menganut prisip-prinsip yang sama dan menempatkan masyarakat sebagai stakeholder yang harus dilayani secara optimal. Moenir berpendapat bahwa layanan kepada pelanggan pendidikan merupakan hak pelanggan pendidikan yang pada dasarnya memiliki prinsip: kesederhanaan, kejelasan, kepastian waktu, akurasi, keamanan, tanggung jawab, kelengkapan sarana dan prasarana, kemudahan akses, kedisiplinan, kesopanan, keramahan, dan kenyamanan. ${ }^{2}$ Dengan memenuhi hak pelanggan pendidikan tersebut, diharapkan lembaga pendidikan bisa meningkatkan mutu layanannya.

Tetapi yang terjadi di lapangan, masih banyak lembaga pendidikan yang masih belum menyadari arti pentingnya pelayanan pelanggan bagi keberhasilan lembaga. Padahal menurut Zeithaml, dkk., lembaga pendidikan adalah lembaga yang paling banyak dituntut kualitas pelayanannya, (8\%) selain pelayanan pemerintah (13\%) dan bisnis profesional (12\%). ${ }^{3}$ Hingga saat ini, masih banyak terdapat sejumlah masalah umum yang dihadapi perusahaan atau lembaga pendidikan untuk memberikan mutu serta layanan yang berkualitas bagi pelanggan. Indikator

${ }^{1}$ Sanad hadits ini dari Abu Umamah (Shady bin Ajlan) ke Al Qasim bin Abdurrahman, ke Ali bin Yazid, ke Ubaidullah bin Zahr, ke Mutharih bin Yazid, ke Ismail bin Ayyasy ke Al Hakam bin Musa ke Abdullah. (Berdasarkan software HadisSoft v.4.o).

${ }^{2}$ Moenir, Manajemen Pelayanan Umum Indonesia, (Bumi Aksara. Jakarta 2002), 41

${ }^{3}$ Valierie A. Zeithaml, dkk, Service Marketing Integrating Customer Focus Across The Firm, Seventh Edition, (New York: McGraw-Hill Education, 2018), 5. 
ketidaktercapainya keberhasilan ini adalah outcame yang dihasilkan masih di bawah standar belum selaras dengan keinginan pelanggan, kemudian kesulitan pelanggan dalam menyampaikan keluhan atau kritikan terhadap lembaga pendidikan dan juga masalah yang membutuhkan waktu yang sangat lama dalam memproses keluhan tersebut, bahkan tidak jarang keluhan atau kritikan tersebut tidak dapat dituntaskan atau direspon oleh lembaga tersebut. Beberapa contoh mengenai keluhan layanan pendidikan diantaranya di Kalimatan Selatan yaitu Ombudsman Banjarmasin mendapat keluhan dari pelanggan pendidikan terhadap lembaga pendidikan soal pungli di sekolah, ijazah yang ditahan, guru tidak mengajar, hingga murid diberhentikan. ${ }^{4}$

Jika dibiarkan, maka hal yang seperti inilah dapat membuat pelanggan kesal dan tidak puas dengan mutu serta layanan yang diberikan kepada pelanggan, sehingga berpotensi untuk berpindahnya pelanggan tersebut kepada pesaing lain (lembaga pendidikan lain). Dampak buruk lainnya dengan kurang maksimalnya mutu layanan pendidikan adalah kurangnya pagu murid, merger, hingga turunnya nilai akreditasi terhadap lembaga pendidikan. Sebagai contohnya kasus di Jembrana, Bali dimana total pendaftar dari enam sekolah swasta, hanya sebanyak 105 pendaftar. Bahkan dari enam sekolah tersebut, ada sekolah yang hanya mendapat tiga dan empat orang siswa, sehingga jika tiap tahunnya terus terjadi maka harus tertutup. ${ }^{5}$ Contoh lain, akibat akreditasi menurun, ratusan siswa SMAN 1 Sampaga melakukan aksi demo di depan sekolah, tuntut kepala sekolah mundur.

Hal itu terjadi karena selain manajemen dari sekolah tersebut yang cenderung otoriter dan tidak memberi pelayanan yang baik kepada siswa dan guru. ${ }^{6}$ Meminjam istilah Buchari Alma, Gerakan para siswa tersebut masuk dalam gejala konsumerisme

\footnotetext{
${ }^{4}$ Fikri, Ombudsman Kalsel Terima 167 Laporan, Mulai Soal Pendidikan hingga THR Tak Dibayar https://www.kanalkalimantan.com/ombudsman-kalsel-terima167-laporan-mulai-soal-pendidikan-hingga-thr-tak-dibayar/ diunduh tanggal 17 Februari 2020.

${ }^{5}$ Ali Mustopa, Jumlah Pendaftar Minim, Sekolah Swasta Terancam Gulung Tikar https://radarbali.jawapos.com/read/2019/o7/11/145654/jumlah-pendaftar-minimsekolah-swasta-terancam-gulung-tikar diunduh tanggal 17 Februari 2019

${ }^{6}$ Kamar, Ratusan Siswa SMAN 1 Sampaga Melakukan aksi Demo di Depan Sekolah, Tuntut Kepala Sekolah Mundur, https://www.radarnusantara.com/2019/o8/ratusan-siswa-sman-1-sampagamelakukan.html diunduh tanggal 17 Februari 2020,
} 
dalam dunia pendidikan. Konsumerisme merupakan suatu kegiatan protes dari pihak konsumen yang mempunyai posisi lemah menghadapi para produsen. ${ }^{7}$ Hal itu terjadi karena pelanggan pendidikan merasa dirugikan karena pihak produsen menjual jasa yang kurang terjamin, kurang bermutu, tidak sesuai dengan yang dijanjikan sehingga banyak mahasiswa atau siswa yang melakukan demonstrasi.

Agar tidak terjadi dampak negatif tersebut, solusinya ada pada kesadaran sumber daya manusia yang berada dalam instansi tersebut, bagaimana suatu instansi tersebut paham akan kualitas mutu layanan yang baik sesuai dengan standar yang ada agar para pelanggan layanaan merasa puas akan layanan yang diberikan, sehingga berpengaruh positif terhadap kinerja yang dihasilkan oleh para pelanggan layanan. Untuk meningkatkan mutu layanan tersebut perlu mengembangkan Total Quality Service atau pelayanan mutu terpadu sebagai bagian dari pelaksanaan manajemen mutu terpadu.

\section{Pembahasan}

\section{Standar Pelayanan dalam Manajemen Mutu Terpadu}

Mengenai kualitas pendidikan, David Wijaya mengemukakan bahwa mengacu pada ISO 9ooo, kualitas atau mutu adalah derajat yang dicapai oleh suatu karakteristik yang melekat untuk memenuhi persyaratan yang ditetapkan. Dalam hal ini, persyaratan adalah kebutuhan atau harapan yang dinyatakan dan biasanya tersirat atau diwajibkan. Jadi, kualitas menurut ISO 9ooo adalah perpaduan antara sifat dan karakteristik yang menentukan sejauh mana keluaran mampu memenuhi persyaratan kebutuhan pelanggan. ${ }^{8}$ Karena itulah perlu adanya tata kelola dan pengarahan yang akan menentukan kebijakan suatu lembaga pendidikan dalam bentuk manajemen mutu terpadu (total quality management).

Manajemen mutu terpadu menurut Edward Sallis merupakan sebuah filosofi tentang perbaikan secara terus menerus yang dapat memberikan seperangkat alat praktis kepada setiap institusi pendidikan (baik sekolah, madrasah, maupun perguruan tinggi) dalam memenuhi kebutuhan, keinginan dan harapan para

\footnotetext{
${ }^{7}$ Buchari Alma, Manajemen Pemasaran dan Pemasaran Jasa, (Bandung: Alfabeta, 2014), 370.

${ }^{8}$ David Wijaya, Pemasaran Jasa Pendidikan, (Jakarta: Bumi Aksara, 2016), 179
} 
pelanggannya, saat ini dan untuk masa yang akan datang. ${ }^{9}$ Juharni juga menambahkan bahwa manajemen mutu terpadu adalah suatu pendekatan dalam menjalankan usaha yang mencoba untuk memaksimalkan daya saing organisasi melalui perbaikan terusmenerus atas produk, jasa manusia, proses, dan lingkungannya. ${ }^{10}$ Hadari Nawawi memberi pandangan lain bahwa manajemen mutu terpadu adalah manajemen fungsional dengan pendekatan secara terus menerus yang difokuskan pada peningkatan kualitas agar produknya sesuai dengan standar kualitas dari masyakarat yang dilayani dalam pelaksanaan tugas pelayanan umum. Dalam hal ini adalah pelayanan umum (public service) dan pembangunan masyarakat (community development). ${ }^{11}$

Dari ketiga pengertian tersebut, terdapat kesamaan dalam hal perbaikan secara berkelanjutan. Namun selain itu ada elemen lain dalam ketiga pengertian manajemen mutu terpadu tersebut yang tidak kalah pentingnya, yaitu peningkatan dalam hal pelayanan pelanggan.

Dalam konteks pendidikan di Indonesia, standar pelayanan dapat kita ambil dari; (1) Standar ISO terbaru, yaitu ISO 21001:2018 ${ }^{12}$ (2) Standar Nasional Pendidikan (SNP) dalam permendiknas No. 19 Tahun 2005, dan (3) Standar Pelayanan Minimal (SPM) dalam SK Menteri Pendidikan Nasional RI No. 129a/U/2004 pasal 3 tentang Standar Pelayanan Minimal. Jika ketiga standar pelayanan dalam ketiga hal tersebut dapat diterapkan oleh lembaga pendidikan, maka tentu peningkatan kualitas layanan terhadap pelanggan pendidikan bisa terpenuhi demi tercapainya manajemen mutu terpadu.

Dari ketiga dimensi tersebut, Standar pelayanan tetap harus mengacu pada prinsip-prinsip dalam manajemen mutu terpadu, sebagai berikut.

${ }_{9}^{9}$ Edward Sallis, Manajemen Mutu Terpadu Pendidikan, (Yogyakarta: IRCiSoD, 2010), 73

${ }^{10}$ Juharni, Manajemen Mutu Terpadu (Total Quality Management), (Makassar: CV Sah Media, 2017), 8

${ }^{11}$ Hadari Nawawi, anajemen strategik organisasi non profit bidang pemerintahan dengan ilustrasi di bidang pendidikan, (Surabaya: Bayumedia, 2003), 46

${ }^{12}$ ISO Central Secretariat, Educational Organization Management Systems, https://isotc.iso.org/livelink/livelink/fetch/$16211625 / 16211627 / 16213175 /$ ISO 21001 -

Briefing Note.pdf?nodeid $=17479885$ \&vernum $=-2$, diunduh tanggal 20 Februari 2020 
Pertama, kepuasan pelanggan. Menurut Kotler, kepuasan merupakan tingkat perasaan ketika seseorang menyatakan hasil perbandingan atas kinerja produk atau jasa yang diterima dengan yang diharapkan. Sementara itu, menurut Gerson David Wijaya, kepuasan pelanggan adalah persepsi pelanggan terkait dengan apakah harapan yang diterima telah terpenuhi dibandingkan dengan ketika menerima kualitas produk atau jasa sebelum membeli. ${ }^{13}$ Kualitas tidak hanya sungguh kesesuaian dengan spesifikasi-spesifikasi tertentu, tetapi kulitas itu ditentukan oleh pelanggan (internal juga eksternal). Contoh dari sebuah lembaga pendidikan yakni memberikan kepuasan mengenai kualitas dalam lembaga pendidikan terhadap warga didalam sekolah ataupun di luar sekolah.

Kedua, keterlibatan karyawan. Semua karyawan berpartisipasi untuk mencapai tujuan bersama. Dalam hal ini, sasaran mutu melibatkan seluruh tingkat, baik tingkat pimpinan (kepala sekolah dan wakil kepala) ataupun karyawan,sehingga sasaran yang ingin dicapai organisasi diketahui oleh semua tingkatan tidak hanya pada level pemimpin. Tindakan ini akan menguntungkan organisasi.

Ketiga, peningkatan berkesinambungan. Komponen utama dari manajemen mutu terpadu adalah perbaikan terus menerus. Perbaikan terus menerus tentu akan menyebabkan peningkatan yang lebih tinggi terhadap mutu proses. Perbaikan terus menerus akan memastikan lembaga pendidikan akan menemukan cara baru dalam memproduksi produk berkualitas lebih baik, produksi menjadi lebih komoetitif, serta melebihi harapan pelanggan.

Keempat, sistem berintegrasi. (1) proses mikro menambah proses yang lebih besar, dan semua proses digabungkann kedalam proses bisnis yang diperlukan untuk menentukan dan menerapkan strategi. Setiap orang dalam lembaga tersebut wajib memahami visi, misi, prinsip serta kebijakan mutu, tujuan, dan proses organisasi. Kinerja dalam lembaga pendidikan harus dipantau dan dikomunikasikan secara terus menerus agar dapat berkembang sesuai yang diharapakan. (2) setiap organisasi memilki budaya kerja yang unik. Dengan demikian, sistem terintegrasi menghubungkan unsur-unsur peningkatan konerja dalam upaya untuk terus meningkatkan dan mencapai harapan pelanggan, karyawan, dan pemangku kepentingan lainnya.

${ }^{13}$ Dalam David Wijaya, Pemasaran Jasa Pendidikan, (Jakarta: Bumi Aksara.2016). 183 
Kelima, pendekatan strategis dan sistematis. Bagian penting dalam manajemen kualitas adalah pendekatan strategis dan sistematis untuk mencapai visi, misi, dan tujuan organisasi. Proses ini biasa disebut manajemen strategis atau perencanaan strategis, termasuk perumusan rencana strategis yang mengintegrasikan kualitas sebagai komponen inti.

Keenam, peningkatan berkelanjutan. Hal utama manajemen mutu terpadu adalah peningkatan proses berkelanjutan. Perbaikan berkelanjutan mendorong organisasi untuk menjadi analitis dan kreatif dalam menemukan cara untuk lebih kompetitif dan lebih efektif dalam memenuhi harapan pemangku kepentingan.

Ketujuh, pembuatan keputusan berdasarkan fakta. Untuk mengetahui seberapa baik kinerja suatu lembaga, data tentang ukuran kinerja sangat diperlukan. Manajemen mutu terpadu mewajibkan lembaga untuk terus mengumpulkan dan menganalisis data guna meningkatkan akurasi pengambilan keputusan, mencapai konsensus, dan memungkinkan prediksi berdasarkan riwayat masa lalu.

Kedelapan, komunikasi. Selama masa perubahan organisasi, serta bagian dari operasi sehari-hari, komunikasi yang efektif memainkan peran besar dalam menjaga moral dan memotivasi karyawan disemua tingkatan. Komunikasi melibatkan strategi, metode, dan ketepatan waktu. Hal ini menciptkan lingkungan keberhasilan dan persatuan serta mendorong hasil proses manajemen mutu terpadu tercapai.

Dari kedepalan prinsip tersebut, menurut Edward Sallis, perlu disinergikanya hubungan antara produsen dan pelanggan pendidikan dalam lembaga pendidikan. Karena mutu lembaga pendidikan harus juga membutuhkan pelanggan Pendidikan sebagai penilai mutu suatu lembaga pendidikan. ${ }^{14}$ Namun menurut Peter Mudie dan Angela Pirrie ada empat karakteristik layanan yang harus dijadikan patokan dalam meningkatkan mutu lembaga, yaitu: intangibility (tidak berwujud), inseparability (ketidakterpisahan), variability (heterogen), dan perishability (mudah rusak). ${ }^{15}$ Jadi perlu dipahami bahwa dalam menerapkan pelayanan yang berbasis manajemen mutu terpadu dalam sebuah lembaga

\footnotetext{
${ }^{14}$ Edward Sallis, Manajemen Mutu Terpadu Pendidikan, Opcit, 82

${ }^{15}$ Peter Mudie dan Angela Pirrie, Services Marketing Management Third Edition, (New York: Elsevier Ltd, 2006), 3-5.
} 
pendidikan adalah proses yang merupakan sinergitas antar seluruh elemen dalam organisasi.

\section{Kesenjangan Pemasar Pendidikan dan Pelanggan Pendidikan}

Untuk dapat bersaing dengan lembaga pendidikan lain, menurut David Wijaya, sekolah perlu melalui pelaksanaan proses jasa pendidikan dengan teratur, dengan mutu yang lebih tinggi dari kompetitor, dan melebihi harapan dari pelanggan jasa pendidikan. Untuk menemukan model mutu layanan jasa pendidikan yang perlu dipenuhi pemasar jasa pendidikan di dalam pelaksanaan proses jasa pendidikan sehingga bisa menyampaikan jasa Pendidikan yang berkualitas tinggi. Parasaruraman, dkk mengemukakan model kesenjangan tersebut dalam bentuk gambar 1 .

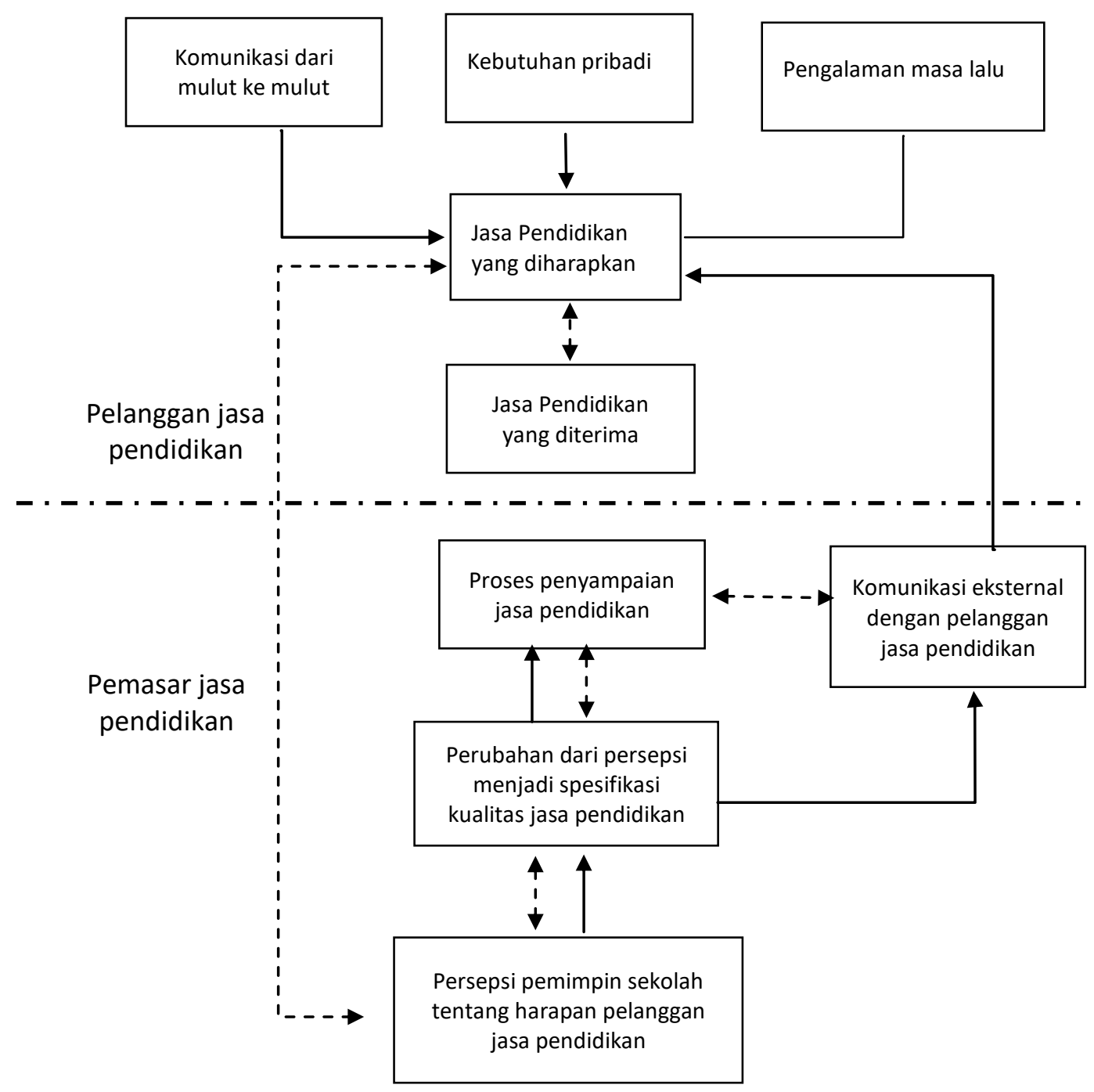


Gambar 1: Model Kualitas Jasa Pendidikan Parasuraman, dkk

Berdasarkan model tersebut, David Wijaya mengemukakan ada lima kesenjangan antara pemasar dan pelanggan pendidikan, yaitu: Kesenjangan persepsi manajemen, Kesenjangan spesifikasi kualitas jasa, kesenjangan proses penyampaian jasa, Kesenjangan komuni-kasi pemasaran, Kesenjangan pelayanan yang dirasakan. ${ }^{16}$ a. Kesenjangan persepsi manajemen

Kesenjangan perspesi manajemen menurut David Wijaya merupakan perbedaan antara penilaian jasa pendidikan yang dilakukan pelanggan pendidikan dan persepsi pemimpin sekolah tentang harapan pelanggan pendidikan. untuk itu, Zeithaml menekankan untuk memperbaiki dan mengevaluasi kembali manajemen tersebut. Dimulai dari kepala sekolah untuk menerapkan karakteristik seorang pemimpin pelayanan, yaitu:

Pertama, service vision (visi pelayanan), yaitu visi seorang pemimpin untuk melihat masa depan organisasi yang berorientasi pada pelayanan yang superior sebagai strategi kemenangan.

Kedua, high standars (standar yang tinggi), pemimpin harus bisa memberi standar yang tinggi dalam pelayanan. Para pemimpin layanan bersemangat untuk melakukan layanan dengan benar. mereka menghargai tujuan yang tanpa cacat, berusaha terus menerus untuk meningkatkan keandalan layanan.

Ketiga, in the field leadership style (gaya kepemimpin di lapangan), pemimpin layanan yang baik adalah pemimpin yang ada di lapangan. Ia mengamati memberi arahan, memperbaiki, dan melahirkan empati yang bisa menggerakkan pendidik dan karyawan dalam melayani pelanggan pendidikan.

Keempat, integrity (integritas), merupakan sebuah karakter penting untuk selalu adil, konsisten, dan bisa dipercaya dalam mengatur segala permasalahan di lembaga pendidikan. ${ }^{17}$

b. Kesenjangan spesifikasi kualitas jasa

${ }^{16}$ David Wijaya, Pemasaran Jasa Pendidikan, (Jakarta: Bumi Aksara, 2016), 192, 196

${ }^{17}$ Valarie A. Zeithaml, Delivering Quality Service, (New York:Simon and Schuster, 1990), 21 
Adalah perbedaan antara persepsi pemimpin sekolah tentang harapan pelanggan pendidikan dan spesifikasi kualitas jasa pendidikan.

c. Kesenjangan proses penyampaian jasa

Adalah perbedaan antara spesifikasi kualitas jasa pendidikan dan proses penyampaian jasa pendidikan.

d. Kesenjangan komunikasi pemasaran

adalah perbedaan antara proses penyampaian jasa pendidikan dan komunikasi eksternal pemasaran jasa pendidikan.

e. Kesenjangan pelayanan yang dirasakan

Adalah perbedaan persepsi antara jasa pendidikan yang dirasakan dan jasa pendidikan yang diharapkan pelanggan jasa pendidikan.

Dari kelima kesenjangan tersebut, terlihat jelas bagaiman kepala sekolah perlu untuk menyamakan persepsi dengan pelanggan pendidikan. Komunikasi menjadi kunci yang harus dibangun antara sekolah dengan masyarakat. Untuk itu humas dan komite sekolah adalah sosok yang tepat dalam menjembatani komunikasi sekolah sehingga tidak terjadi kesenjangan.

\section{Servqual dalam Manajemen Pemasaran Pendidikan}

Salah satu pendekatan kualitas jasa yang banyak digunakan sebagai acuan dalam riset pemasaran adalah model Servqual (Service Quality) yang dikembangkan oleh Zeithaml, Berry, serta Parasuraman. Menurut Muhammad Tajuddin, dkk., Servqual merupakan perbandingan antara apa yang serharusnya ditawarkan (offered) dan apa yang disediakan (provided). ${ }^{18}$ Muhammad Tajuddin, dkk, menambahkan bahwa terdapat dua hal penting yang dikembangkan dalam meningkatkan kualitas pelayanan, yaitu: 1) sistem informasi untuk keperluan manajemen dan motivasi karyawan, dan 2) sistem informasi yang digunakan untuk menyebarkan nilai (value) bermanfaat bagi para pelanggan sistem informasi.

Menurut Andriani Kusumawati, Servqual adalah sebuah model yang digunakan untuk mengukur kualitas layanan. Zeithaml dan Parasuraman mengajukan model ini sejak tahun 1985. Model

${ }^{18}$ Muhammad Tajuddin, dkk. Kesuksesan Sistem Informasi Perguruan Tinggi dan Good University Governance. Sebuah kajian empiris di perguruan tinggi swasta, (Malang:UB Press, 2016), 8. 
ini biasa disebut gap model karena celah yang diidentifikasi antara harapan pelanggan dan persepsi pelanggan perlu ditutup untuk menawarkan kualitas yang sangat baik. ${ }^{19}$

Kualitas Pelayanan (Q) = Ekspektasi (E) - Persepsi (P)

Jadi Servqual digagas berdasarkan pandangan bahwa penilaian pelanggan terhadap kualitas pelayanan sangat penting.

Model Servqual diterapkan dengan melakukan perbandingan terhadap dua faktor utama yang memengaruhi kualitas jasa, yaitu persepsi pelanggan terhadap jasa nyata yang diterima (perceived service) dan persepsi pelanggan terhadap jasa yang sesungguhnya diharapkan (expected service). Apabila kualitas jasa yang diterima lebih tinggi dari kualitas jasa yang diharapkan maka jasa aka dikatakan berkualitas, demikian sebaliknya. Jadi, kualitas jasa dapat didevinisikan sebagai seberapa jauh perbedaan antara kenyataan dan harapan pelanggan atas layanan yang diterima.

Menurut Parasuraman yang dikutip oleh David Wijaya, terdapat lima dimensi Servqual yang dikenal dengan istilah RATER. RATER ini dapat diterapkan dalam dunia pendidikan dan terdiri Reliability, Assurance, Tangible, Empathy, dan Responsiveness.

1. Reliability (keandalan), yaitu kemampuan sekolah untuk menyediakan jasa pendidikan sesuai dengan janji secara akurat dan terpercaya.

2. Assurance (jaminan), yaitu pengetahuan, kesopansantunan, dan kemampuan karyawan sekolah untuk menumbuhkan tingkat kepercayaan pelanggan jasa pendidikan terhadap sekolah meliputi komunikasi, kepercayaan, keamanan, kompetensi, dan sopan santun.

3. Tangible (berwujud), yaitu kemampuan sekolah untuk menunjukkan dirinya pada pihak eksternal sekolah.

4. Empathy (empati), yaitu sekolah mampu memberikan perhatian yang tulus dan pribadi ke pelanggan jasa pendidikan dengan memahami keinginan pelanggan jasa pendidikan.

5. Responsiveness (ketanggapan), yaitu kebijakan untuk membantu serta memberikan jasa pendidikan yang cepat dan tepat kepada pelanggan jasa pendidikan. ${ }^{20}$

\footnotetext{
${ }^{19}$ Andriani Kusumawati, Perilaku Konsumen dan Pemasaran Pendidikan Tinggi (Malang:UB Press, 2010), 27.

${ }^{20}$ David Wijaya, Pemasaran Jasa Pendidikan, (Jakarta: Bumi Aksara.2016). 181-182
} 
Dari Gambar 2 bisa kita simpulkan bahwa RATER membawa peran krusial dalam kepuasan pelanggan. Bahkan melalui pelayanan maksimal mendapat tempat yang pertama dalam penentuan kepuasan pelanggan, kualitas produk kedua, dan harga adalah yang terakhir. Kepuasan pelanggan tersebut merupakan hasil dari dua faktor, yaitu faktor situasi dan faktor personal. Dari kepuasan pelanggan tersebut akhirnya melahirkan loyalitas pelanggan. Dalam dunia pendidikan, loyalitas pelanggan bisa kita jumpai dari orang tua yang secara aktif menyekolahkan anak-anaknya ditempat yang sama, atau alumni yang membentuk ikatan alumni yang secara aktif

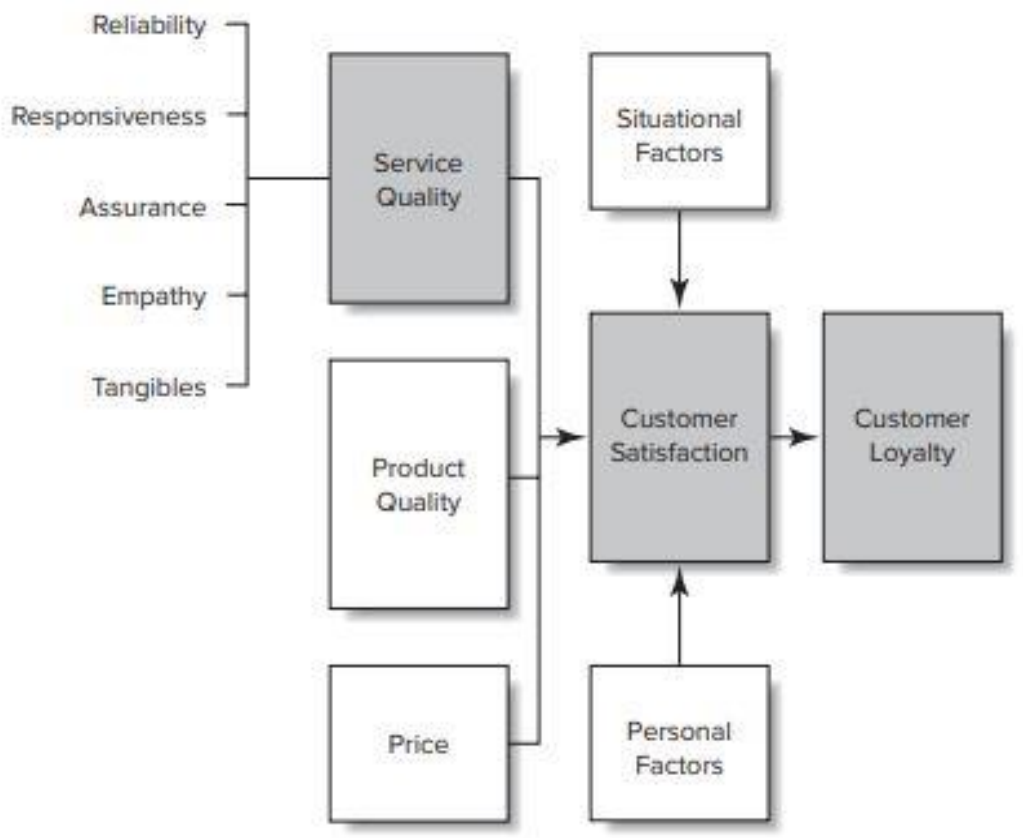

Gambar 2. Customer Perceptions of Quality and Customer Satisfaction ${ }^{21}$

merekomendasikan sekolah atau pondok pesantrennya kepada keluarga, kerabat, teman, dan tetangga-tetangga untuk menyekolahkan anaknya ditempat dia belajar.

Penilaian kinerja kepala madrasah dimaksudkan untuk menilai sejauhmana seorang kepala madrasah mengejawantahkan kompetensi-kompetensi yang dipersyaratkan dalam melaksanakan tugas dan fungsinya sehari-hari. Penilaian kinerja kepala madrasah

${ }^{21}$ Valarie A. Zeithaml, dkk, Services Marketing: Integrating Customer Focus Across The Firm, Seventh Edition (New York: McGraw-Hill Education, 2018), 79 
difokuskan pada unsur-unsur kinerja yang terkait langsung dengan dimensi-dimensi kompetensi yang dipersyaratkan tersebut. Unsurunsur penilaian ini hendaknya merupakan satu kesatuan yang masing-masing memiliki bobot yang relatif sama dalam penentuan hasil akhir penilaian kinerja seorang kepala madrasah. Pada kenyataannya, setiap dimensi kompetensi kepala sekolah/madrasah sebagaimana tercantum dalam Permendiknas Nomor 13 Tahun 2007 memiliki keluasan cakupan yang berbeda.Oleh karena itu penggunaan langsung dimensi-dimensi itu sebagai aspek penilaian kinerja kepala madrasah dapat berdampak pada kekurangsahihan hasil penilaian.

Oleh karena itu, perlu dirumuskan kembali aspek-aspek penilaian yang memiliki bobot dan ruang lingkup yang relatif sama, namun tetap dalam kerangka lima dimensi kompetensi. Perumusan aspek-aspek ini dilakukan dengan cara mengelompokkan kompetensi yang serumpun ke dalam aspek yang sama. Berdasarkan karakteristik masing-masing, kompetensi-kompetensi itu dikelompokkan ke dalam enam aspek, yakni: kepribadian dan sosial, kepemimpinan pembelajaran, pengembangan sekolah/madrasah, manajemen sumber daya, kewirausahaan, supervisi pembelajaran

\section{Implementasi Servqual RATER dalam Meningkatkan Mutu Lembaga Pendidikan Menyongsong Revolusi Industri 4.o}

Menurut Kotler, Hermawan dan Iwan, perubahan besar dari pemasaran yang digerakkan oleh produk (1.0) ke pemasaran yang berpusat pada pelanggan (2.0) menjadi pemasaran yang pada akhirnya berpusat pada manusia (3.0). Pemasaran 4.0 adalah pendekatan pemasaran yang menggabungkan interaksi online dan offline antara perusahaan dan pelanggan. Dalam ekonomi digital, interaksi digital saja tidak cukup. Faktanya, dalam dunia yang semakin online, sentuhan offline mewakili diferensiasi yang kuat. ${ }^{22}$ Berdasarkan pengertian tersebut, Kotler, dkk menambahkan bahwa terdapat tiga ciri-ciri revolusi industri 4.o, yaitu: dari eksklusif ke inklusi, dari vertikal ke horizontal, dari individual ke sosial. ${ }^{23}$ Ketiganya merupakan konklusi gerakan revolusi industri, 4.o, yaitu dari tradisional ke digital. Jadi untuk mengimplementasikan

\footnotetext{
${ }^{22}$ Philip Kotler, Hermawan Kartajaya and Iwan Setiawan, Marketing 4.o Moving from Traditional to Digital (New Jersey: John Wiley \& Sons Inc., 2017), 47.

${ }^{23}$ Ibid, 7-15.
} 
Servqual dalam meningkatkan mutu layanan pemasaran pendidikan di era revolusi industri 4.o, maka lembaga pendidikan perlu mengimplementasikan langkah-langkah seperti dalam tabel berikut:

Table 1 : implementasi Servqual RATER dalam revolusi industri 4.0

\begin{tabular}{|l|l|l|l|}
\hline \multicolumn{1}{|c|}{ JENIS LAYANAN } & $\begin{array}{c}\text { EKSKULIF KE } \\
\text { INFKLUSIF }\end{array}$ & $\begin{array}{l}\text { VERTIKAL KE } \\
\text { HORISONTAL }\end{array}$ & $\begin{array}{l}\text { INDIVIDUAL } \\
\text { KE SOSIAL }\end{array}$ \\
\hline Reliability & e-learning & $\begin{array}{l}\text { Seleksi terbuka } \\
\text { guru melalui CAT } \\
\text { dan siswa melalui } \\
\text { UTBK }\end{array}$ & $\begin{array}{l}\text { Tugas } \\
\text { kelompok } \\
\text { melalui } \\
\text { penilaian } \\
\text { viewers }\end{array}$ \\
\hline Assurance & $\begin{array}{l}\text { Checklock/finger } \\
\text { print }\end{array}$ & $\begin{array}{l}\text { Seleksi beasiswa } \\
\text { online }\end{array}$ & e-raport \\
\hline Tangible & $\begin{array}{l}\text { Ada website } \\
\text { sekolah }\end{array}$ & $\begin{array}{l}\text { Lelang proyek } \\
\text { online }\end{array}$ & $\begin{array}{l}\text { Promosi di } \\
\text { medsos }\end{array}$ \\
\hline Emphaty & $\begin{array}{l}\text { Perijinan } \text { online } \\
\text { Ucapan bela } \\
\text { sungkawa melalui } \\
\text { medsos }\end{array}$ & Donasi digital \\
\hline Responsiveness & $\begin{array}{l}\text { Kritik saran via } \\
\text { medsoss }\end{array}$ & $\begin{array}{l}\text { Pengumuman } \\
\text { sekolah melalui } \\
\text { medsos }\end{array}$ & $\begin{array}{l}\text { Grup WA wali } \\
\text { murid }\end{array}$ \\
\hline
\end{tabular}

Penjabaran dari tabel tersebut adalah sebagai berikut:

a. Dari layanan eksklusif menjadi inklusif

Layanan eksklusif adalah layanan berbasis perangkat keras (hardware), di era 3.0 layanan seperti ini merupakan hal yang dianggap maju, namun di era sekarang, layanan hardware mulai ditinggalkan banyak perusahaan/organisasi karena memakan banyak biaya dan tempat sehingga mereka berpindah ke perangkat lunak (software). Sebagai buktinya, banyak orang lebih suka belajar di youtube, atau aplikasi ruang guru ketimbang membayar orang lain untuk melakukan les privat. Kemudahan dan kepuasan yang dialami oleh pelanggan pendidikan membuat lembaga pendidikan perlu menginklusifkan layanannya. Di perguruan tinggi misalnya sudah ada layanan daftar skripsi, KRS, wisuda, dan lain-lain melalui aplikasi kampus sehingga mereka tidak perlu antri di akademik untuk mengurus hal itu.. ditingkat SMA juga dilakukan terobosan dengan melakukan e-raport, dimana orang tua bisa melihat raport anaknya dari HP. Contoh lain yang bisa diimplementasikan Servqual RATER antara lain: 
Pertama, E-learning ${ }^{24}$ merupakan bentuk keandalan dari sebuah lembaga pendidikan. Dengan adanya e-learning, sekolah membuktikan bahwa mereka memiliki komputer, jaringan internet yang kuat, guru dan murid yang menguasai IT. (Reliability)

Kedua, aplikasi checklock/finger print adalah aplikasi yang bisa menjamin anak benar-benar masuk sekolah dan pulang tepat pada waktunya, caranya adalah dengan mengkoneksikan aplikasi tersebut pada server sekolah lalu mengirimkan pesan ke wali murid. Aplikasi ini juga menjamin guru untuk mengajar sesuai jamnya dan meminimalisir guru yang membolos karena juga ditetapkan sebagai acuan tunjangan profesi guru. ${ }^{25}$ (Assurance)

Ketiga, keberadaan website sekolah merupakan bentuk nyata bahwa sekolah tersebut benar-benar ada dan informasi mengenai sekolah tersebut bisa diakses dimana-mana. Sedangkan data yang ditampilkan harus benar-benar sesuai dengan data di dapodik. Dengan adanya website sekolah, menurut kementerian pendidikan dan kebudayaan terdapat beberapa manfaat, yaitu: memudahkan pencarian sekolah sekitar wilayah, melihat profil sekolah, melakukan perbandingan sekolah, melihat peta sebaran sekolah, melihat komentar terhadapat sekolah. ${ }^{26}$ (Tangible)

Keempat, orang tua dari siswa yang sakit akan kesulitan jika harus mengirim surat ijin ke sekolah. Apalagi jika rumahnya jauh dan harus meninggalkan anaknya hanya untuk mengirim surat ijin sekolah. Disinilah peran sekolah sebagai bentuk perhatian dan empati kepada siswa yang sakit. Karena itulah sekolah perlu melonggarkan aturan dengan pemberian ijin melalui WA atau mengupload surat sakitnya. Begitu juga dengan perijinan kepentingan keluarga dan lainnya. (Empathy)

\footnotetext{
${ }^{24}$ Permendikbud Nomor 109 Tahun 2013 pasal 1 ayat 3 tentang Penyelenggaraan Pendidikan Jarak Jauh Pada Pendidikan Tinggi sudah mengeluarkan kebijakan mengenai e-learning dalam penyenggaraan pendidikan Pembelajaran elektronik (e-learning) adalah pembelajaran yang memanfaatkan paket informasi berbasis teknologi informasi dan komunikasi untuk kepentingan pembelajaran yang dapat diakses oleh pesertadidik kapan saja dan di mana saja

${ }^{25}$ Imam Solehudin, "Guru Wajib Ngajar 8 Jam Sehari, Jadi Patokan Tunjangan Profesi," http://www.jawapos.com/nasional/pendidikan/26/11/2018/guru-wajibngajar-8-jam-sehari-jadi-patokan-tunjangan-profesi/, diakses tanggal 14 Maret 2020.

${ }^{26}$ Kementerian Pendidikan dan Kebudayaan, "Tahukah Anda Tentang Website Sekolah Kita?," http://ditpsmp.kembidkbud.go.id/tahukah-anda-tentangwebsite-sekolah-kita/ diakses tanggal 14 Maret 2020.
} 
Kelima, membuka kontak kritik dan saran melalui email, ${ }^{27}$ WA atau media sosial. ${ }^{28}$ Dengan adanya layanan ini, sekolah menjadi lebih cepat dalam merespon kesulitan dengan adanya laporan atau keluhan di kontak kritik dan saran. (Responsiveness)

b. Dari layanan vertikal menjadi horisontal.

Layanan verktikal adalah layanan dari atas kebawah, artinya secara birokrasi, hal itu sangat menyulitkan karena memakan waktu. Sedangkan layanan horisontal adalah layanan yang mendatar, artinya semua pihak baik internal sekolah maupun eksternal sekolah memiliki andil dalam pengembangan sekolah. Untuk memangkas birokrasi tersebut di era revolusi industri 4.0 dalam rangka peningkatan kualitas layanan, perlu dilakukan beberapa cara:

Pertama, seleksi guru melalui Computer Assited Test seperti dalam perekrutan CPNS adalah bentuk transparansi. Sekolah perlu mendesain penyeleksian agar seluruh pihak eksternal sekolah juga bisa menjangkau dalam pengembangan sekolah. Bentuk tes tulis ujian masuk secara terbuka $\left(\right.$ UTBK ${ }^{29}$ juga merupakan bentuk keandalan sekolah dalam perekrutan untuk meminimalisir jalur masuk melalui jalur belakang atau ilegal. (Reliability)

Kedua, pemerintah memiliki program melalui Kartu Indonesia Pintar, pun begitu dengan program beasiswa lainnya. Dengan adanya seleksi online dan uji publik tentu akan membuat beasiswa tersebut tepat sasaran. ${ }^{30}$ Hal ini akan memudahkan pelayanan dan jaminan tepat sasaran dalam menyalurkan beasiswa ke anak yang benar-benar tidak mampu karena masyarakat sosial juga bisa menilainya. (Assurance)

Ketiga, seringkali sekolah melakukan renovasi gedung namun proyek tersebut perencanaan proyek tersebut cenderung rahasia dan tidak transparan. Untuk meminimalisir hal tesebut, sekolah perlu melakukan lelang online atau e-lelang dalam proyek

\footnotetext{
${ }^{27}$ Rob Stokes and the Minds of Quirk, eMarketing: The essential guide to marketing in a digital world Fifth Edition (Quirk Education Pty, 2013), 405

${ }^{28}$ ibid. 435

${ }^{29}$ Permenristekdikti Nomor 6o Tahun 2018 Tentang Penerimaan Mahasiswa Baru Program Sarjana Pada Perguruan Tinggi Negeri Pasal 1 ayat 5.Ujian Tulis Berbasis Komputer yang selanjutnya disingkat UTBK adalah ujian tulis yang dilakukan dengan menggunakan sarana komputer.

${ }^{30}$ Contoh uji publik beasiswa pemkab Jember seperti dalam website online berikut: https://radarjember.jawapos.com/headline/23/o8/2019/uji-publik-10ooo-beasiswa/
} 
pembangunan sekolah. Untuk memenuhi pelayanan tersebut, pemerintah sudah menyiapkan website khusus untuk lelang di wilayah Kementerian Pendidikan dan Kebudayaan ${ }^{31}$ atau Kementerian Agama. ${ }^{32}$ Hal itu akan membuat layanan masyarakat bisa lebih aktif dalam pengembangan sekolah. (Tangible)

Keempat, jika ada musibah, baik adanya orangtua siswa yang meninggal maupun kecelakaan, sekolah perlu menyampaikan simpatinya dengan ucapan belasungkawa. Namun seringkali sekolah hanya menyampaikan secara face to face terhadap keluarga sehingga masyarakat umum tidak mengetahui bentuk perhatian sekolah. Untuk itu perlu bagi sekolah untuk menampilkan rasa belasungkawanya melalui website resmi atau media sosial resmi sekolah. ${ }^{33}$ (Emphaty)

Kelima, pengumuman-pengumuman sekolah perlu disampaikan secara tertulis di website atau sosial media resmi sekolah. Hal ini adalah bentuk gerak cepat dari sekolah jika ada kebijakan baru dari atas maupun hasil kebijakan kepala sekolah. ${ }^{34}$ (responsiveness)

c. Dari layanan individual menjadi sosial

Saat ini masih banyak layanan-layanan yang bersifat individual. Artinya semua dilakukan dengan sendiri. Sementara masyarakat pasif dan hanya menerima saja. Namun era sekarang, masyarakat sosial bisa berpartisipasi.

Kedua, pemberian tugas kelompok guru kepada siswa terkadang sangat subjektif. Karena itulah dalam penilain perlu penilaian objektif. Salah satunya adalah pemberian tugas melalui upload video tugas melalui media sosial. Dari jumlah viewers dan subscribers guru bisa menilai cara siswa bersosialisasi tidak hanya di dunia nyata tapi di dunia maya. Seperti contoh video yang

\footnotetext{
${ }^{31}$ Kemdikbud, "Layanan Pengadaan Secara Elektronik" 2006. "Layanan Pengadaan Secara Elektronik" 2016. https://lpse.kemdikbud.go.id/eproc/lelang (20 Februari 2020)

32 Kemenag, "Layanan Pengadaan Secara Elektronik" 2006. https://lpse.kemenag.go.id/eproc/lelang (20 Februari 2020)

33 Contoh ucapan belasungkawa melalui website sekolah seperti yang dicontohkan SMPN 3 Denpasar berikut: http://www.smpnzdps.sch.id/pengumuman/77-ucapan-bela-sungkawa.html 34 Contoh pengumuman sekolah bisa dilihat melalui link berikut: http://web.smanijember.sch.id/informasi.html
} 
diunggah pelajar SMAN 1 Narmada tentang pembelahan sel. ${ }^{35}$ Video yang diunggah 5 Desember 2018 tersebut mencatatkan 25 ribu kali tayangan. (Reliability)

Kedua, e-raport ${ }^{36}$ adalah bentuk jaminan ketuntasan belajar dan pengolahan nilai dalam bentuk aplikasi. Selain memangkas kertas, orang tua juga bisa mengakses di mana saja dan kapan saja sehingga jaminan ketuntasan belajar anak terpantau dengan mudah, cepat dan akurat. (Assurance)

Ketiga, Kotler manyatakan bahwa lembaga perlu menunjukkan keberadaannya melalui promosi. Dalam teori promotional mix yang ditawarkan Kotler, salah satunya adalah advertisement, ${ }^{37}$ jadi sekolah perlu untuk membuat brosur online yang hars disebar oleh wali murid, siswa, alumni, guru dan karyawan sekolah dalam rangka menunjukkan keberadaan sekolah di media sosial. (Tangible)

Keempat, di setiap lembaga, musibah seringkali datang baik dalam bentuk robohnya bangunan, orang tua siswa meninggal, siswa kecelakaan, pembangunan musola sekolah dan lain-lain. Untuk menunjukkan bentuk empati, tidak hanya kepala sekolah dan guru, tapi bisa dari siswa, orang tua siswa, atau masyarakat sekitar sekolah bisa untuk menyampaikan empatinya melalui donasi. Untuk mempermudah, perlu adanya donasi digital untuk orang yang ingin berempati dengan melalui transfer e-banking atau gopay. Sebagai contoh SMAN 2 Blora memuat donasi online di websitenya untuk pembangunan masjid sekolah. ${ }^{38}$ (Emphaty)

Tiap wali kelas perlu membuat grup dengan orang tua siswa masing-masing. Dengan adanya komunikasi wali kelas dan wali murid, maka akan segera keluhan bisa segera disampaikan guru melalui rapat guru atau langsung disampaikan ke kepala sekolah. Bukan tidak mungkin bahwa cepatnya tindakan sekolah dalam

35 Taqiyya Zaida, "Sel tumbuhan xi $m \quad 1 \quad$ sman 1 narmada", 2018 https://www.youtube.com/watch?v=4WT1K1diBis (20 Februari 2020)

${ }^{36}$ e-raport mulai diterapkan di sekolah menengah dengan diterapkannya surat edaran no. 8/D/KR/2017 tentang pengisian nilai akhir raport, us, dan usbn di dapodik.

${ }^{37}$ Kotler dan Keller, Marketing Management 13th Edition, (Edinburg: Pearson, 2016), 579.

38 https://smanegeri2blora.sch.id/read/54/donasi-pembangunan-masjid-alhakim-sma-negeri-2-blora 
merespon komunikasi tersebut akan melahirkan pemasaran bentuk promosi sosial media. ${ }^{39}$ (Responsiveness)

\section{Simpulan}

Kajian ini sampai pada empat simpulan. Pertama, standar pelayasan sekolah haruslah mengedepankan kepuasan pelanggan pendidikan sehingga sinergi antara sekolah, murid, dan wali murid sangat diperlukan. Kedua, mengurangi kesenjangan yang terjadi dalam dunia pendidikan dengan meningkatkan komunikasi yang tepat. Ketiga, Servqual yang paling tepat diimplementasikan dalam dunia pendidikan adalah RATER. Keempat, implementasi RATER dalam era 4.0 adalah melalui digitalisasi sehingga bisa menjangkau pelanggan dengan lebih luas, praktis dan cepat tanpa mengurangi kualitas dari pelayanan sekolah. Pendidikan di Indonesia sangat memungkinkan dalam mengimplementasikan Servqual RATER dalam meningkatkan mutu layanannya. Modal memang diperlukan untuk proses digitalisasi untuk itu perlu ada sinergi antara sekolah dengan pemerintah dan wali murid sebagai pelanggan pendidikan agar tujuan utama pendidikan yaitu untuk mencerdaskan kehidupan bangsa bisa tercapai.

\section{Referensi}

Alma, Buchari. Manajemen Pemasaran dan Pemasaran Jasa, Bandung: Alfabeta. 2014.

Chikandiwa, Sarah Tsitsi. The Role of Social Media in The Marketing Communication Mix. Thesis, Administration \& Law at the University of Zululand. 2013.

Fikri, "Ombudsman Kalsel Terima 167 Laporan, Mulai Soal Pendidikan hingga THR Tak Dibayar" https://www.kanalkalimantan.com/ombudsman-kalselterima-167-laporan-mulai-soal-pendidikan-hingga-thr-takdibayar/ (17 Februari 2020)

39 Sarah Tsitsi Chikandiwa, The Role of Social Media in The Marketing Communication Mix (Thesis, Administration \& Law at the University of Zululand), 29. 
https://radarjember.jawapos.com/headline/23/o8/2019/uji-publik10-ooo-beasiswa/

ISO Central Secretariat, "Educational Organization Management Systems,” $\quad$ https://isotc.iso.org/livelink/livelink/fetch/16211625/16211627/16213175/ISO 21001 Briefing Note.pdf?nodeid $=17479885 \&$ vernum $=-2, \quad$, $\quad$ (20 Februari 2020)

Juharni. Manajemen Mutu Terpadu (Total Quality Management). Makassar: CV Sah Media. 2017.

Kamar. "Ratusan Siswa SMAN 1 Sampaga Melakukan aksi Demo di Depan Sekolah, Tuntut Kepala Sekolah Mundur," https://www.radarnusantara.com/2019/o8/ratusan-siswasman-1-sampaga-melakukan.html (17 Februari 2020)

Kemdikbud, "Tahukah Anda Tentang Website Sekolah Kita?," http://ditpsmp.kembidkbud.go.id/tahukah-anda-tentangwebsite-sekolah-kita/ (14 Maret 2020)

Kemenag, “Layanan Pengadaan Secara Elektronik" 2016. https://lpse.kemenag.go.id/eproc/lelang (20 Februari 2020)

Kotler, Philip, Kartajaya, Hermawan dan Setiawan, Iwan. Marketing 4.0 Moving from Traditional to Digital. New Jersey: John Wiley \& Sons Inc. 2017.

Kotler, Philip dan Keller, Kevin Lane. Marketing Management 13th Edition. Edinburg: Pearson. 2016.

Kusumawati, Andriani. Perilaku Konsumen dan Pemasaran Pendidikan Tinggi. Malang:UB Press. 2010.

Moenir. Manajemen Pelayanan Umum Indonesia. Bumi Aksara. Jakarta. 2002.

Mudie, Peter dan Pirrie, Angela. Services Marketing Management Third Edition. York: Elsevier Ltd. 2006.

Mustopa, Ali. "Jumlah Pendaftar Minim, Sekolah Swasta Terancam Gulung Tikar" https://radarbali.jawapos.com/read/2019/o7/11/145654/juml ah-pendaftar-minim-sekolah-swasta-terancam-gulung-tikar (17 Februari 2019) 
Nawawi, Hadari. Manajemen Strategik Organisasi Non Profit Bidang Pemerintahan Dengan Ilustrasi di Bidang Pendidikan. Surabaya: Bayumedia, 2003.

Permendikbud Nomor 109 Tahun 2013 pasal 1 ayat 3 tentang Penyelenggaraan Pendidikan Jarak Jauh Pada Pendidikan Tinggi

Permenristekdikti Nomor 6o Tahun 2018 Tentang Penerimaan Mahasiswa Baru Program Sarjana Pada Perguruan Tinggi Negeri Pasal 1 ayat 5.

Solehudin, Imam. "Guru Wajib Ngajar 8 Jam Sehari, Jadi Patokan Tunjangan Profesi," 2018. http://www.jawapos.com/nasional/pendidikan/26/11/2018/g uru-wajib-ngajar-8-jam-sehari-jadi-patokan-tunjanganprofesi/, (14 Maret 2020)

Surat Edaran Kementerian Pendidikan dan Kebudayaan No. 8/D/KR/2017 tentang pengisian nilai akhir raport, US, dan USBN di dapodik.

Stokes, Rob and the Minds of Quirk. eMarketing: The essential guide to marketing in a digital world Fifth Edition. Quirk Education Pty. 2013.

Tajuddin, Muhammad, dkk. Kesuksesan Sistem Informasi Perguruan Tinggi dan Good University Governance. Sebuah Kajian Empiris di Perguruan Tinggi Swasta. Malang:UB Press. 2016.

Wijaya, David. Pemasaran Jasa Pendidikan. Jakarta: Bumi Aksara. 2016.

Sallis, Edward. Manajemen Mutu Terpadu Pendidikan. Yogyakarta: IRCiSoD. 2010.

Zeithaml, Valierie A. dkk, Service Marketing Integrating Customer Focus Across The Firm, Seventh Edition. New York: McGraw-Hill Education, 2018.

Zeithaml, Valarie A. Delivering Quality Service. New York:Simon and Schuster. 1990. 